\title{
Binary Microbe System for Biological Control of Fusarium Wilt of Tomato: Enhanced Root-Colonization of an Antifungal Rhizoplane Bacterium Supported by a Chitin-degrading Bacterium
}

\author{
Hideyoshi ToYoda*, Masayuki Morimoto*, Koji KaKutani*, \\ Masaaki MoRIKaWA*, Tamo FuKamizo**, Sachio Goto**, \\ Hikojiro TERADA* and Seiji OuCHI*
}

\begin{abstract}
An antagonistic rhizoplane bacterium (Serratia marcescens) and a chitin-degrading microbe (Streptomyces anulatus) were used for establishing a binary microbe system for biological control of Fusarium wilt disease of tomato. For effectively tracing rootcolonization, the rhizoplane bacterium was genetically marked with the lux genes and the tetracycline resistance gene through bacterial conjugation. Successful colonization by the bacterium on roots from bacterized seeds was visualized by bioluminescence of the transconjugant into which the $l u x$ gene operon had been integrated. Antifungal activity of the transconjugant was stable and effective even when the bacterium was colonized on tomato roots. Multiplication of the transconjugant in soil was supported by the chitin-degrading microbe which had been previously added in chitin-supplemented soil. The chitin-degrading microbe produced extracellular endochitinases and hydrolyzed chitin which was added to soil. Chitohydrolytic products supported the multiplication and root-colonization of the rhizoplane bacterium in soil. The binary microbe system comprising of chitin-degrading microbe and gene-marked transconjugant was effective in controlling of tomato wilt disease caused by Fusarium oxysporum f. sp. lycopersici.
\end{abstract}

(Received October 5, 1992)

Key words: Serratia marcescens, Streptomyces anulatus, lux gene operon, transconjuga tion, biological control, Fusarium oxysponum f. sp. lycopersici.

\section{INTRODUCTION}

Biological control has been a novel strategy for protecting crop plants from soilborne plant pathogens ${ }^{3,23,32)}$. Some microorganisms have been isolated from soil or plant roots and applied in order to antagonize pathogens in the plant rhizospher ${ }^{1,30)}$. In most cases, however, it has been difficult to stabilize the antifungal activities of these microbes in soil ${ }^{6}$, mainly because of a rapid decrease in their population ${ }^{2,32)}$. Therefore, it is important to stabilize populations of these microbes in soil.

It has long been known that an amendment of chitin to soil was effective in suppressing the infection of some plant pathogens ${ }^{4,28,29}$. The application of chitin promoted the multiplication of chitin-degrading microbes and made these microbes dominant in soil and/or rhizosphere ${ }^{18}$. Although the relationship between chitin-degrading microbes and plant pathogens has not been well elucidated, these results lead us to postulate that antagonistic microbes would preferentially multiply and therefore provide a

* Laboratory of Plant Pathology and ** Laboratory of Physical Chemistry, Faculty of Agriculture, Kinki University, Nakamachi 3327-204, Nara 631, Japan 近畿大学農学部 
long-term protection of crop plants from diseases, provided they were capable of catabolizing chitins applied to soil. In addition, the protective effects would be amplified if the antagonists colonized better on the surface of plant roots. The present paper describes the binary microbe system, a model system for efficiently stabilizing the colonization of a rhizoplane bacterium at root surface with an aid of a chitin-degrading microbe.

\section{MATERIALS AND METHODS}

Proposed system for bacterization. The binary microbe systern for bacterization devised in this study is characterized by the use of two different microorganisms in chitin-amended soil : one is a chitin-degrading microbe (CDM), and the other a root-colonizing bacterium (RCB). In the system, CDM supplies carbon source for the multiplication of antagonistic rhizoplane bacteria which colonize on newly developing roots and protect plants from pathogens. According to this design, RCB with antifun. gal activity was isolated in the following experiment.

Isolation of rhizoplane bacteria. Tomato plants (Lycopersicon esculentum cv. Ponderosa) growing in the field were collected, and their roots were washed exhaustively and homogenized with sterilized water. Cell debris was eliminated by membrane filtration (membrane pore size, $3 \mu \mathrm{m}$ diameter), and the clarified homogenate was centrifuged at $12,000 \times \mathrm{g}$, for $20 \mathrm{~min}$. The pellet was suspended in M9 minimal medium ${ }^{16)}$ lacking carbon source, shake-cultured for $6 \mathrm{hr}$, and spread onto a solidified agar. Surface-sterilized tomato seeds which had been previously germinated were placed onto a water agar and incubated further at $26^{\circ} \mathrm{C}$ for 2-3 days until bacterial colonies were formed around seedling roots. These bacteria were isolated as putative rhizoplane bacteria and assayed for their antifungal activity.

Assay for antifungal activity. Two different methods were used for examining the antifungal activity of isolated bacteria ; one is a spore-plate method, and the other a pair-culture method. In the first method, isolated bacteria were spotted onto solid PCG medium ( $10 \mathrm{~g}$ of Bactopeptone, $1 \mathrm{~g}$ of casamino acid, $10 \mathrm{~g}$ of glucose in 1 liter of water, $1.5 \%$ agar) and incubated at $26^{\circ} \mathrm{C}$ for 3 days. Bacteria-spotted plate was cut and laid onto an agar-solidified Czapek medium ( $3 \mathrm{~mm}$ thick) in which conidiospores ( $10^{6}$ spores $/ \mathrm{ml}$ ) of $F$. oxysporum f. sp. lycopersici (race J1) had been embedded. After 2-3 days of incubation, the antifungal activity was assessed by measuring the transparent zone formed as a consequence of suppression of the mycelial growth. In the second method, the fungal inoculum was placed at the center of agar medium plate, and test bacteria were spotted at positions $3 \mathrm{~cm}$-distant from the pathogen. The antifungal activity was determined by measuring radial growth of fungal colony after 10 days of incubation. Finally, the bacterial isolate with the strongest antifungal activity was selected and designated as KM-201.

Test for root-colonizing affinity. Tomato seeds were surface-sterilized with $2 \%$ sodium hypochlorite and $75 \%$ ethanol, and rinsed several times with sterilized water. Surface-sterilized seeds were immersed in bacterial suspension with different densities $\left(10^{4}-10^{8}\right.$ cells $\left./ \mathrm{ml}\right)$ for $30 \mathrm{sec}$, blotted with paper, and incubated at $26^{\circ} \mathrm{C}$ on filter paper laid onto a water agar for germination. After 5 days of incubation, germinated seeds (root length of $8-10 \mathrm{~cm}$ ) were transferred to PCG medium in order to detect bacteria which colonized on newly elongated roots.

Genetical marking of KM-201 and Southern hybridization. KM-201 was transformed with the transposon Tn4431 which contains promoterless luciferase gene operon (lux) of Vibrio fischeri linked to tetracycline resistance gene ${ }^{26)}$. The vector pUCD623 carrying Tn4431 was transferred to the recipient KM-201 from the donor bacterium (Escherichia coli HB101) according to the biparental mating method $^{33)}$. Transconjugants were isolated on the selective medium $(10 \mu \mathrm{g} / \mathrm{ml}$ tetracycline-containing CCpA medium where sucrose of Czapek medium was replaced with $10 \mathrm{mg} / \mathrm{ml}$ chitopentose), and exposed for 2-4 hr in darkness to X-ray film to obtain luminiferous bacteria. Consequently, the transconjugant (KM-201/lux ) with the strongest bioluminescence was selected and used for the following experiment.

Chromosomal DNA was extracted from KM-201/lux according to the method of Marmur ${ }^{17}$, digested with some restriction enzymes, electrophoresed in $1 \%$ agarose gel, transferred to nitrocellulose 
membrane, and hybridized to the non-radioactive probe (lux DNA) labeled with horseradish peroxidase. Labeling and detection of DNA was carried out by the method described previously ${ }^{31}$.

Evaluation of root-colonization. Non-sterilized tomato seeds were coated with $\mathrm{KM}-201 /$ lux , sown in non-sterilized soil, and incubated at $26^{\circ} \mathrm{C}$ under a continuous illumination of 8,000 lux in the growth chamber. Plants were harvested at various periods of times after sowing. Root tips ( $1 \mathrm{~cm} \mathrm{long)}$ were excised, homogenized and diluted with water, and spread onto the selective medium (tetracyclinecontaining $\mathrm{CCpA}$ medium). After 2 days of incubation, the numbers of luminiferous colonies were estimated using the X-ray film method.

Assay for TM-3 chitinase. A chitinolytic isolate (Streptomyces anulatus, TM-3) from our laboratory stock was used for the present study. For examining chitinase production, TM-3 was shake-cultured at $26^{\circ} \mathrm{C}$ for a specified period of times in a liquid CC medium (without agar) where sucrose of Czapek medium was replaced with $10 \mathrm{mg} / \mathrm{ml}$ pure chitin (Nacalai Tesque Inc., Tokyo, Japan). Culture filtrate was membrane-filtered (pore size, $0.22 \mu \mathrm{m}$ diameter), dialysed against 20 volumes of $50 \mathrm{mM}$ phosphate buffer ( $\mathrm{pH} 6.5)$, and used as the enzyme solution. The enzyme solution $(0.5 \mathrm{ml})$ was mixed with $1 \mathrm{ml}$ of the reaction mixture containing $0.05 \%(\mathrm{w} / \mathrm{v})$ glycolchitin in $50 \mathrm{mM}$ sodium phosphate buffer $(\mathrm{pH}$ 6.5), and incubated at $37^{\circ} \mathrm{C}$ for $1 \mathrm{hr}$. Chitinase activity was determined colorimetrically by estimating the reducing groups from glycolchitin with the potassium ferri-ferrocyanide reagent by the method of Imoto and Yagishita ${ }^{13)}$. Total protein contents were measured according to the method of Bradford ${ }^{5)}$.

The mode of chitin hydrolysis was analyzed by high performance liquid chromatography (HPLC) of gel permeation system ${ }^{9}$. A model substrate, chitopentose, was added to dialyzed culture filtrate of TM-3 and incubated at $37^{\circ} \mathrm{C}$ for $1 \mathrm{hr}$. The hydrolyzate was then charged to linearly linked, two gel permeation column YSK-GEL $(0.7 \times 60 \mathrm{~cm}$, Toyo Soda, Tokyo, Japan), and was eluted with distilled water at a flow rate of $0.3 \mathrm{ml} / \mathrm{min}$ under the pressure of $25 \mathrm{~kg} / \mathrm{cm}^{2}$. The eluates were monitored by absorption at $220 \mathrm{~nm}$ to determine their retension times relative to specific peaks of synthetic oligochitosaccharides and $\mathrm{N}$-acetylglucosamine.

Growth of TM-3 in chitin-amended soil. TM-3 growing exponentially in liquid CC medium was collected, suspended in water, mixed with sterilized chitin-amended soil (100 mg chitin per $1 \mathrm{~g}$ soil), and incubated at $26^{\circ} \mathrm{C}$. Soil sample $(1 \mathrm{~g})$ was harvested at various intervals, diluted with sterilized water, and spread on CCA medium. After 5 days of incubation, colonies were counted to estimate colonyforming units (CFU) per $1 \mathrm{~g}$ of soil.

Test for protection efficiency of the binary microbe system. The three-layer method described previously ${ }^{21)}$ was used for evaluating a protection efficiency by the present system. The spore-plate was used for the bottom layer. Namely, conidiospores $\left(10^{6}\right.$ spores $\left./ \mathrm{ml}\right)$ of $F$. oxysporum $\mathrm{f}$. sp. lycopersici were suspended in melted Czapek medium and solidified at the bottom of a culture vessel. Over this spore-plate were layered $10 \mathrm{~cm}$ thick of non-sterilized soil (middle layer) and then nonsterilized chitin-amended soil (top layer) which had been incubated at $26^{\circ} \mathrm{C}$ with TM-3 for 30 days. As a control, chitin-free soil with or without TM-3 was used as the top layer. Tomato seeds coated with $\mathrm{KM}-201 /$ lux were sown in the top layer soil and incubated at $26^{\circ} \mathrm{C}$ for 30 days in the growth chamber. The pathogen propagules in the middle and top layer soils or in root homogenates were determined at the end of experiment, by spreading water suspension of these soils or diluted homogenates on Komada's selective medium ${ }^{15}$, respectively. KM-201/lux was re-isolated from the top layer soils and root homogenates, using the selective $\mathrm{CCpA}$ medium and the $\mathrm{X}$-ray film method.

\section{RESULTS}

\section{Isolation of $R C B$ with antifungal activity}

In this experiment, we obtained 52 different bacterial colonies from homogenates of exhaustively washed tomato roots, and selected antifungal species of bacteria from these isolates using the sporeplate method (Plate I-1). Eventually, 12 antifungal isolates were obtained and tested for their colonization capability by the seed-coating method. The isolate KM-201 showed the effective colonization on the entire surface of roots even when the lowest colonization at the whole surface of roots even when the 
lowest density of bacteria $\left(10^{4} \mathrm{cells} / \mathrm{ml}\right)$ was used for seed-coating (Plate $\left.\mathrm{I}-2\right)$. The antifungal activity of KM-201 was further confirmed by pair-culture with the pathogen $(F$. oxysporum f. sp. lycopersici) (Plate I-3). From these results, KM-201 was adopted as RCB in the present system. Prior to an actual application, some characteristics of this bacterium were examined according to the methods of Smibert and $\mathrm{Krieg}^{27)}$, and finally KM-201 was identified as Serratia marcescens (data not shown).

\section{Genetical marking of $\mathrm{KM}-201$}

In the present experiment, about 200 tetracycline resistant transconjugants were obtained from biparental mating of each $10^{9}$ donor and recipient cells, and 5 of these transconjugants showed bioluminescence. Bioluminescence of a transconjugated bacterium (KM-201/lux) was shown in Plate I-4. An integration of the marker genes into this luminiferous bacterium was verified by Southern hybridization analysis of chromosomal DNA with the probe lux genes (Fig. 1). Plate I-3 indicated that KM-201/ lux expressed the antifungal activity at a similar level to that of the original bacterium.

Root-colonization by KM-201/lux was tested by sowing bacterium-coated tomato seeds in a soil and gently pressing plant roots (harvested 15 days after sowing) onto the selective medium. Plate I- 5 shows bioluminescence produced by KM-201/lux colonized on newly elongated roots. Thus, the genetically

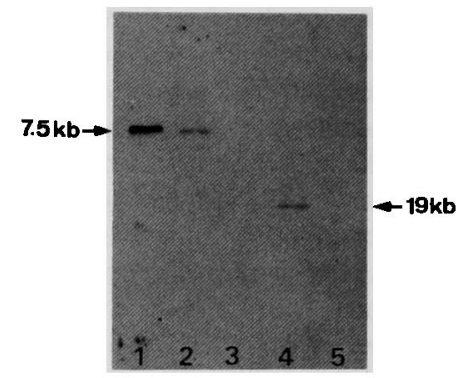

Fig. 1. Southern hybridization analysis of KM-201/lux chromosomal DNA. Chromosomal DNAs of KM-201 (lanes, 3 and 5) and transconjugant KM-201/lux (2 and 4) were digested with Bam H1 (2 and 3) or Pst 1 (4 and 5), electrophoresed, and hybridized with the labeled probe (7.5 kb lux operon excised out of the original vector pUCD623).

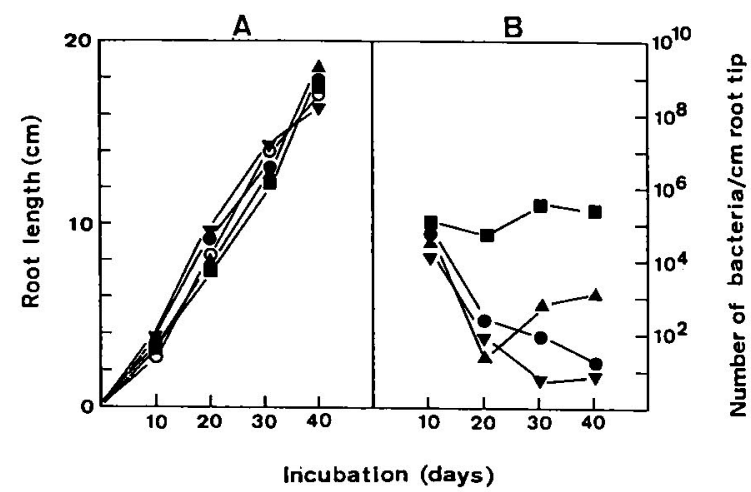

Fig. 2. Growth of tomato roots (A) and change of population of KM-201/lux colonized on root tips (B). Tomato seeds coated with KM-201/lux were grown in chitin-free soil without TM-3 (๑), chitinamended soil preincubated for 30 days with TM-3 (a), chitin-amended soil without TM-3 (A), and chitin-free with TM-3 $(\nabla)$. Root elongation $(O)$ of non-coated seeds in chitin-free soil was given as a control for checking detrimental effect of the present treatment on the elongation of tomato roots. The tips ( $1 \mathrm{~cm}$-long) were excised from 5 roots picked up at random, homogenized, and spread onto the selective medium. The data were given as means of three separate replications. 
Table 1. Some characteristics of microbes used for the binary microbe system

\begin{tabular}{|c|c|c|c|}
\hline & \multicolumn{3}{|c|}{ Microbes } \\
\hline & \multirow{2}{*}{$\begin{array}{c}\text { Streptomyces anulatus } \\
\text { TM-3 }\end{array}$} & \multicolumn{2}{|c|}{ Serratia marcescens } \\
\hline & & KM-201 & $\mathrm{KM}-201 / \operatorname{lux} x^{\mathrm{a})}$ \\
\hline \multicolumn{4}{|l|}{ Growth on mediab) } \\
\hline potato sucrose agar (PSA) & + & + & $+d)$ \\
\hline potato dextrose agar (PDA) & + & + & + \\
\hline Czapek $\mathrm{N}$-acetylglucosamine agar (CAgA) & + & + & + \\
\hline Czapek chitopentose agar (CCpA) & + & + & + \\
\hline Czapek colloidal chitin ${ }^{\mathrm{el}}$ agar (CCoA) & + & \pm & \pm \\
\hline Czapek chitin agar (CCA) & + & - & - \\
\hline M9 minimal dextrose agar (M9) & \pm & + & + \\
\hline Antifungal activity to $F$. oxysporum f. sp. lycopersici & - & + & + \\
\hline Colonization to tomato root & - & + & + \\
\hline Tetracycline resistance & - & - & + \\
\hline Bioluminescence & - & - & + \\
\hline
\end{tabular}

a) A Tn4431 mutant of KM-201 containing the luciferase gene operon (lux) and the tetracycline resistance gene.

b) Concentration of carbon source added to medium was $10 \mathrm{mg} / \mathrm{ml}$.

c) Colloidal chitin was prepared by treating powder chitin with $56 \%(\mathrm{v} / \mathrm{v})$ aqueous methanesulfonic acid according to the method of Hirano and Nagao ${ }^{11}$.

d) + , vigorous growth; \pm , slight growth; - , no growth.

marked bacterium (KM-201/lux) successfully retained the original characteristics required for RCB.

In the following experiment, the stability or effectiveness of root-colonization by this bacterium was evaluated by checking localization of KM-201/lux at tip portion of newly elongating roots. Figure $2 \mathrm{~A}$ shows elongation of tomato roots and change of population of KM-201/lux colonized on root tips. Although KM-201/lux was detected on all of newly elongated root tips, but the population was gradually lowered with an increased elongation of roots. Such a decrease of bacterial population was considered to be a major cause for loss or reduction of protection effect by RCB. In order to support the stable proliferation of RCB, therefore, we integrated CDM into our biocontrol system, since it has been known that some strains of $S$. marcescens utilize the digestion products of chitin for the growth ${ }^{8,199}$.

Chitin-catabolization by KM-201/lux

The catabolizing ability of chitin-hydrolyzates is essential for RCB to utilize carbon source supplied by a chitin-degrading microbe. We therefore tested KM-201/lux for its capability to catabolize chitin or chitin-hydrolyzates (Table 1). The bacterium grew at a slow rate when colloidal chitin was supplied as a sole carbon source, but did not show any significant growth when pure chitin was added. On the contrary, KM-201/lux multiplied vigorously in the presence of $\mathrm{N}$-acetylglucosamine or chitopentose, indicating that it can utilize hydrolyzed products more effectively than colloidal or pure chitin. These properties of KM-201/lux were closely similar to the original bacterium KM-201 (Table 1).

It has been generally recognized that antifungal activity of antagonistic microbes frequently varies depending on the medium used for assay ${ }^{2}$. Therefore, the antifungal activity of $\mathrm{KM}-201 /$ lux was examined using the spore-plate method. KM-201/lux was proliferated on CCpA medium for 2 days, and then the medium plate was placed on the spore-plate of Fusarium. The clear antifungal activity of KM-201/lux was shown in Plate I-6. These results suggest that the growth of KM-201/lux in rhizosphere could be supported when coupled with the microbe which digests chitin and provides chitin-hydrolyzates such as chitopentose.

\section{Chitinase production by CDM}

The secondary approach was to utilize the microbe which hydrolyzes chitin to support the growth of RCB. It has been known that populations of fungal plant pathogens decrease while chitinolytic microbes preferentially increase in soils amended with chitin ${ }^{4,18}$. Also in the present study, we used the chitinolytic isolate, TM-3 which had been isolated from field soil repeatedly amended with crab shell chitin. Some properties of TM-3 were also given in Table 1 . 


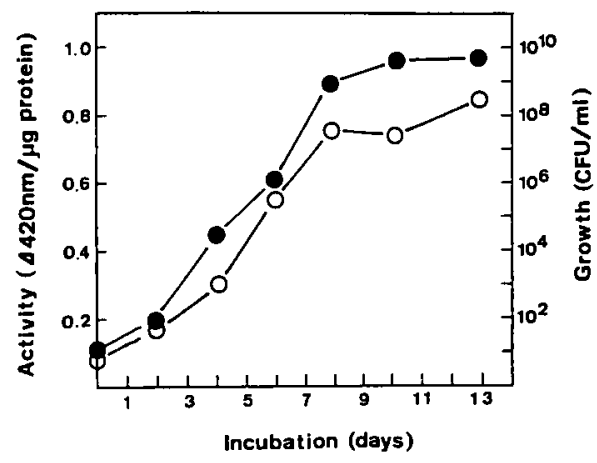

Fig. 3. Time course of the growth of Streptomyces anulatus TM-3 (-) and the activity of extracellular chitinases $(O)$ released into liquid $\mathrm{CC}$ medium.

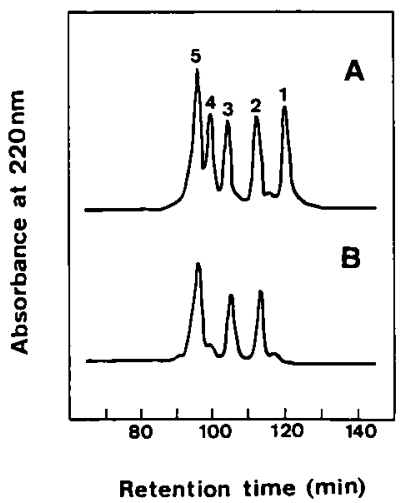

Fig. 4. HPLC analysis of hydrolytic products of chitopentose by chitinases of Streptomyces anulatus TM-3. A, Specific peaks of authentic chitopentose (5), chitotetrose (4), chitotriose (3), chitobiose (2), and $\mathrm{N}$-acetylglucosamine (1) ; B, Elution profile of products from digestion of chitopentose by TM-3 chitinases.

As shown in Plate I-7, TM-3 produced halo when embedded in CCA medium. This clearly indicates that the production of a halo was due to digestion of chitin by extracellular chitinases of these isolates and the digestion products were utilized for their growth. Figure 3 represents changes of the growth and extracellular chitinase activity of TM-3 shake-cultured in liquid CC medium. To further characterize chitinase produced by TM-3, we examined the mode of digestion of chitopentose by TM- 3 culture filtrate. The HPLC analysis of enzyme products revealed that chitobiose and chitotriose were mainly produced by digestion of the substrate (chitopentose), indicating that the major fraction of chitinases released by TM-3 was endotype (Fig. 4).

\section{Precedence of TM-3 in chitin-amended soil}

Since the precedence of CDM in soil is a prerequisite to the present system, it was examined whether the growth of TM-3 in soil could be accelerated by chitin amendment. TM-3 was precultured in liquid CC medium to activate the chitinase production and inoculated into chitin-amended soil. In this experiment, autoclaved chitin-amended soil was used because of easy and effective detection of TM-3 proliferated in soil. As shown in Fig. 5, TM-3 initiated the exponential growth without an apparent lag phase and reached the maximum level $\left(10^{\circ} \mathrm{CFU} / \mathrm{g}\right.$ soil) 20 days after inoculation. On the other hand, the growth of TM-3 in control (without chitin) was slow and the population was less than $10^{3} \mathrm{CFU} / \mathrm{g}$ soil 


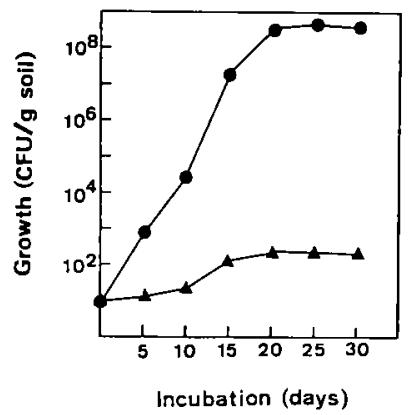

Fig. 5. Growth of TM-3 in autoclaved chitin-free $(\Delta)$ and chitin-amended (•) soil. Each value is a mean of three separate experiments.

at the end of incubation. Thus, TM-3 was shown to be prominently accelerated by the addition of chitin to soil.

In the following experiment, it was examined whether the growth of KM-201/lux could be promoted in chitin-amended soil where TM-3 preceded. With the pair-culture method, it was preliminarily confirmed that KM-201/lux and TM-3 were not antagonistic to each other. Tomato seeds coated with KM-201/lux were sown in non-sterilized chitin-amended soil which had been preliminarily incubated with TM-3 for 30 days. These treatments did not cause any detrimental effects on root elongation (Fig. 2B). Figure 2-B showed change of population of KM-201/lux monitored on root tips. The result clearly indicated that KM-201/lux was stably maintained at the initial level throughout the experimental periods of 40 days. On the other hand, KM-201/lux did not show any prominent growth in chitinamended soil without TM-3 or in chitin-free soil with TM-3. These results strongly supported our experimental design that chitin-hydrolyzates supplied by CDM can promote the stable multiplication and root-colonization of $\mathrm{RCB}$ used for seed-coating.

\section{Suppression of fungal pathogen by the binary microbe system}

In order to experimentally verify effectiveness of the present system, disease appearance was tested using the three-layer method (Table 2). First, we tried to isolate the pathogen from the middle layer soils, because the successful invasion of the pathogen was prerequisite for establishing the effective infection. The pathogen was constantly re-isolated $\left(2-4 \times 10^{5} \mathrm{CFU} / \mathrm{g}\right.$ soil) with no relation to soil samples overlaid, indicating that the pathogen embedded in the agar-plate can invade into the upper soil layers. In addition, the high level $\left(10^{6} \mathrm{CFU} / \mathrm{g}\right.$ soil) of the pathogen was also detected in the top-layer soil when non-coated tomato seeds were grown in chitin-free soil without TM.3. Under this condition, all of tested seedlings were wilted within 30 days after sowing (Plate I-8, left). These results further confirmed that the present method allowed the pathogen to effectively invade and attack host plants. The prominent protection was observed when KM-201/lux-coated seeds were sown in chitin-amended soil preliminarily treated with TM-3 (Plate I-8, right). In this top-layer soil, the pathogen was inhibited to be less than $10^{2}$ $\mathrm{CFU} / \mathrm{g}$ soil, and the population of KM-201/lux was considerably high (more than $10^{5} \mathrm{CFU} / \mathrm{gr}$. soil) throughout the experimental periods. Although the protection effect was also observed when non-coated seeds were sown in chitin-amended soil with TM-3, the efficiency was not so high as that found in the former case. On the contrary, the protection was inefficient when KM-201/lux-coated seeds were sown in chitin-free soil with TM-3 or in chitin-amended soil without TM-3. Thus, the present study revealed that the Fusarium wilt disease of tomato was effectively controlled when the present binary microbe system was completely furnished.

\section{DISCUSSION}

It has been generally accepted that root colonization and multiplication of introduced antagonistic bacteria is essential for effective biocontrol of root pathogens ${ }^{32}$. The system proposed in this study 
Table 2. Protection ${ }^{\text {" }}$ of fusarial wilt disease of tomato by the binary microbe system using the antagonistic rhizoplane bacterium KM-201/lux and chitin-degrading microbe TM-3

\begin{tabular}{|c|c|c|c|c|c|c|c|c|}
\hline \multicolumn{2}{|c|}{$\begin{array}{c}\text { Construction } \\
\text { of } T \mathrm{~L}\end{array}$} & \multirow{2}{*}{$\begin{array}{l}\text { Seed coating } \\
\text { with } \\
\text { KM-201/lux }\end{array}$} & \multirow{2}{*}{$\begin{array}{c}\text { Disease } \\
\text { rates }^{c)} \\
(\%)\end{array}$} & \multicolumn{3}{|c|}{$\begin{array}{c}\text { Pathogen }{ }^{d} \\
\text { (CFU/g sample) }\end{array}$} & \multicolumn{2}{|c|}{$\begin{array}{c}\text { KM.20l/lux } \\
\text { (CFU/g sample) }\end{array}$} \\
\hline chitin & TM-3 & & & $\mathrm{ML}$ & $T L$ & RH & TL & $\mathrm{RH}$ \\
\hline- & - & - & 100 & $10^{5}-10^{6}$ & $10^{6}$ & $10^{6}$ & - & - \\
\hline+ & - & + & 82.4 & $10^{5}$ & $10^{5}$ & $10^{5}$ & $<10^{2}$ & $<10^{4}$ \\
\hline- & + & + & 92.6 & $10^{5}$ & $10^{5}$ & $10^{5}$ & $<10^{2}$ & $<10^{2}$ \\
\hline+ & + & - & 38.3 & $10^{5}$ & $10^{2}-10^{6}$ & $10^{4}$ & - & - \\
\hline+ & + & + & 2.5 & $10^{5}$ & $<10^{2}$ & $<10^{2}$ & $>10^{5}$ & $>10^{5}$ \\
\hline
\end{tabular}

a) The protection efficiency was evaluated using the three-layer method comprising the bottom layer for the spore-plate embeded with conidiospores of the pathogen $(F$. axysporum $\mathrm{f}$. $\mathrm{sp}$. lycopersici), the middle layer (ML) for soil without chitin and TM-3, and the top layer (TL) for sample soils.

b) Tomato seeds were immersed in suspension ( $\left.10^{4} \mathrm{cells} / \mathrm{ml}\right)$ of KM-201/lux for $30 \mathrm{sec}$, blotted with paper, sown in the top layer soil, and incubated for 30 days.

c) The rate of wilted tomato seedlings. Twenty seedlings were used for each experiment.

d) The pathogen and KM-201/lux used for seed-coating were re-isolated from middle and top layer soils and root homogenates $(\mathrm{RH})$ at the end of experiment using a Komada's medium and tetracycline-containing selective medium, respectively.

The data in the table were given as averages of three separate experiments.

supports in principle this basic assumption, as demonstrated by antagonistic bacteria (KM-201) and its transconjugant (KM-201/lux). Since successful isolation of promising bacteria largely depends on specific interactions (including chemical interaction) between plant root and bacteria ${ }^{12}$, we used a simple agar plate to select the bacteria which grow on root surface as a result of utilization of root exudate as a sole source of nutrients. The bacterial isolate (KM-201) obtained from homogenate of thoroughly washed tomato roots showed a high affinity to tomato root, but not to those of other plant species such as strawberry and melon plants (data not shown). This specific affinity may reflect differences in constituents of root exudates ${ }^{1,20)}$.

Howie et al. ${ }^{121}$ proposed a hypothesis as to the colonization of Pseudomonas fluorescens on wheat roots, differentiating the process of root colonization into two phases; phase I for attachment controlled by root exudates and phase II for transport and multiplication of bacteria. The successful rootcolonization by our isolate also implies that the bacteria attached to seed surface are transported along elongating roots to their tips, although the mechanism of bacterial transport has not been elucidated.

We have demonstrated the antifungal activity of KM-201 (and its transconjugant) to $F$. oxysporum f. sp. lycopersici. The activity was very stable and non-specific, inhibiting the growth of a broad range of Fusarium species (data not shown). We have partially purified antifungal substance from the culture filtrates of these bacteria and found that the compound inhibited both spore germination and mycelial elongation of Fusarium species (unpublished data). Since the production of antifungal substance by the bacteria is not affected by carbon sources added to medium, the long-term, stable protection would be expected provided their populations are maintained stably on the rhizoplane or in rhizosphere.

The binary microbe system proposed in this study aims at increasing populations of root-colonizing, antifungal bacterium by a nutrient-supplying microbe. Successful construction of this system was largely dependent on integration of effective chitin-degrading microbes. TM-3 had the highest chitinase activity among our chitin-degrading isolates, and was most suppressive for the growth of Fusarium in combination with the present rhizoplane bacterium. As far as we examined, TM-3 did not show any antifungal activity against the pathogenic fungi under the conditions where chitinases were not produced. These results strongly suggest that the chitinase production is the crucial function of TM-3 in the binary system. Mitchell and Alexander ${ }^{18)}$ reported that chitin application to soil led to decreased population of fungal plant pathogens with increased population of chitinolytic microbes. The TM-3 treated soil in this study also considerably suppressed the propagation of $F$. oxysporum without the antagonistic rhizoplane bacterium (See Table 2). Recently, we have analyzed cell wall components of 
this pathogen by solid state ${ }^{13} \mathrm{C}$-NMR analysis and found that the major component is chitin including chitosan $^{10)}$. In addition, it was shown that cell wall fraction prepared from $F$. oxysporum was completely digested by TM. 3 chitinases (unpublished data). Although the evidence for the role of chitinases in fungal disease control is still indirect, the correlation is strong and suggestive enough to postulate that the higher activity of TM-3 chitinases is functional in supplying chitin-hydrolyzed products to RCB after digestion of fungal cell wall of the pathogen. The suppressive effect of the present system is most probably due to combination of the production of antifungal substances by KM-201 (and KM-201/lux) and chitinases by TM-3.

Monreal and Reese ${ }^{19)}$ reported that chitinases of S. marcescens QMB1466 can hydrolyze crystallin chitin, and Roberts and $\mathrm{Cabib}^{22}$ purified chitinases from this bacterium. Genes encoding chitinases in this strain were also characterized by some workers ${ }^{8,14,24}$. By the use of gene manipulation technologies, Jones et al ${ }^{14)}$ and Shapira et al ${ }^{24)}$ substantially verified a possible application of chitinases to biological control of $F$. oxysporum f. sp. pisi and Sclerotium rolfsii, respectively. The root-colonizing bacterium KM-201 that we isolated from tomato root homogenate was also $S$. marcescens, but this isolate was different from QMB1466 in the capability of chitin hydrolysis. Inability of KM-201 to hydrolyze pure chitin (crystallin chitin) is due probably to the lack of some genes for extracellular chitinases. If KM-201 was transformed with chitinase genes of QMB1466, our system for biological control could be effectuated by the use of such species of bacteria. Bacterial conjugation used in this study may be applicable to the intraspecies transfer of chitinase gene in $S$. marcescens.

Adequate estimation of root colonization by bacteria requires an efficient and precise method for tracking the introduced bacterium. Drahos et al." utilized $E$. coli $\beta$-galactosidase gene as a selective marker gene and traced the recombinant $P$. fiuorescens in soil. Shaw and Kado ${ }^{251}$ and Shaw et al ${ }^{263}$ reported a transposon mutagenesis for monitoring phytopathogenic bacteria transformed with the lux gene operon $(l u x)$ and detected bacteria in planta in a non-disruptive manner. These genetic recombination techniques provided reliable method for evaluating the behavior of introduced bacteria in soil. Especially, the transformation with $l u x$ genes is useful and applicable to visualization of rootcolonization by introduced bacteria. By the application of this transposon mutagenesis, we obtained a luminiferous root-colonizing transconjugant. Bioluminescence emission in this transconjugant implies, as indicated by Shaw et $a l^{26)}$, that promoterless $l u x$ operon was functionally integrated into chromosomal DNA at the downstream region of some resident promoter of KM-201. Although an integration of foreign DNA sequences may inactivate some of host bacterial genes, we succeeded in isolating a mutant that conserved genes for characteristics of RCB and enabled us to verify that the bacterium can move from coated seed and colonize on elongating tomato roots.

The present study demonstrated that the binary microbe system is effective for protecting tomato plants from the wilt caused by $F$. oxysporum $\mathrm{f}$. sp. lycopersici. The mechanism for the protective effect could be substantially analyzed using a luminiferous transconjugant. The protection is due to a successful root-colonization of antagonistic bacterium under the support by the chitin-degrading microbe, and that the bacteria adhered to seed surface are transported to the root tips. Since these bacteria preferentially grow with a carbon source supplied by CDM, they can also proliferate in the rhizosphere (see Table 2). Increase of population of rhizosphere bacteria may not only promote a secondary adhesion to root surface, but also enhance the suppression of the growth of pathogen. Low density of Fusarium fungi in soils amended with chitin and inoculated with TM-3 and KM-201/ lux strongly support this possibility. A similar protective effect would be expected even if the original isolate, KM-201 was used for bacterization, because the original bacterium satisfies the characteristics required for RCB. In the present study, all of the experiments were carried out in a closed system in order to prevent release of genetically engineered bacteria to the environment. In the subsequent study, the validity of this binary microbe system will be tested under field conditions.

\section{Literature cited}

1. Azad, H.R., Davis, J.R., Schnathorst, W.C. and Kado, C.I. (1985). Relationships between rhizoplane and rhizosphere bacteria and verticillium wilt resistance in potato. Arch. Microbiol. $140: 347-351$. 
2. Baker, K.F. and Cook, R.J. (1982). Approaches to biological control with antagonistic microorganisms. In Biological control of plant pathogens. The American Phytopathological Society, St. Paul. pp. 107-134.

3. Baker, K.F. (1987). Evolving concepts of biological control of plant pathogens. Ann. Rev. Phytopathol. 25: $67-85$

4. Boller, T. (1986). Chitinase: A defense of higher plants against pathogens. In Chitin in Nature and Technology (Muzzarelli, R. C. et al. eds.). Plenum Press, New York. pp. 223-230.

5. Bradford, M.M. (1976). A rapid and sensitive method for the quantitation of microgram quantities of protein utilizing the principle of protein-dye binding. Anal. Biochem. 72: 248-254.

6. Cook, R.J. (1970). Factors affecting saprophytic colonization of wheat straw by Fusarium roseum $\mathrm{f}$. sp. cerealis 'Culmorum'. Phytopathology $60: 1672-1676$.

7. Drahos, D.J., Hemming, B.C. and Mcpherson, S. (1986). Tracking recombinant organisms in the environment: $\beta$-galactosidase as a selectable non-antibiotic marker for fluorescent Pseudomonads. Bio/Technology $4: 439-444$.

8. Fughs, R.L., Mcpherson, S.A. and Drahos, D.J. (1986). Cloning of a Serratia marcescens gene encoding chitinase. Appl. Environ. Microbiol. 51 : 504-509.

9. Fukamizo, T., Torikata, T., Kuhara, S. and Hayashi, K. (1982). Human lysozyme-catalyzed reaction of chitooligosaccharides. J. Biochem. 92: 709-716.

10. Fukamizo, T., Sonoda, K., Toyoda, H., Ouchi, S. and Goto, S. (1990). Solid state ${ }^{13}$ C-NMR analysis of cell wall components of Fusarium oxysponum. Agric. Biol. Chem. 54 : 2761-2762.

11. Hirano, S. and Nagao, N. (1988). An improved method for the preparation of colloidal chitin by using methanesulfonic acid. Agric. Biol. Chem. $52: 2111-2112$.

12. Howie, W.J., Cook, R.J. and Weller, D.M. (1987). Effects of soil matric potential and cell motility on wheat root colonization by fluorescent pseudomonads suppressive to take-all. Phytopathology $77: 286-292$.

13. Imoto, T. and Yagishita, K. (1971). A simple activity measurement of lysozyme. Agric. Biol. Chem. 35 : 1154-1156.

14. Jones, J.D.G., Grady, K.L., Suslow, T.V. and Bedbrook, J.R. (1986). Isolation and characterization of genes encoding two chitinase enzymes from Serratia marcescens. EMBO J. 5: 467-473.

15. Komada, H. (1975). Development of a selective medium for quantitative isolation of Fusarium oxysporum from natural soil. Rev. Plant Prot. Res. 8: 114-125.

16. Maniatis, T., Fritsch, E.F. and Sambrook, J. (1982). Propagation and maintenance of bacterial strains and viruses. In Molecular cloning. Cold Spring Harbor Laboratory, New York. pp. 55-73.

17. Marmur, J. (1961). A procedure for the isolation of deoxyribonucleic acid from microorganisms. J. Mol. Biol. $3: 208-218$.

18. Mitchell, R. and Alexander, M. (1962). Microbiological processes associated with the use of chitin for biological control. Soil Sci. Soc. Proc. 26 : 556-558.

19. Monreal, J. and Reese, E.T. (1969). The chitinase of Serratia marcescens. Can. J. Microbiol. 15: 689-696.

20. Neal, J.L. Jr., Atkinson, T.G. and Larson, R.I. (1970). Changes in the rhizosphere microflora of spring wheat induced by disomic substitution of a chromosome. Can. J. Microbiol. 16: 153-158.

21. Ouchi, S., Toyoda, H., Morimoto, M., Kurusu, T., Matsuda, Y., Goto, S. and Fukamizo, T. (1992). Integration of chitin-degrading microbes into biological control system for Fusarium wilt of strawberry. In Biological Control of Plant Diseases (Tjamos, E.S. ed.). Plenum Press, New York. pp. 335-339.

22. Roberts, R.L. and Cabib, E. (1982) Serratia marcescens chitinase: One-step purification and use for the determination of chitin. Anal. Biochem. 127: 402-412.

23. Schippers, B., Bakker, A.W. and Bakker, P.A.H.M. (1987). Interactions of deleterious and beneficial rhizosphere microorganisms and the effect of cropping practices. Ann. Rev. Phytopathol. 25: 339-358.

24. Shapira, R., Ordentlich, A., Chet, I. and Oppenheim, A.B. (1989). Control of plant diseases by chitinase expressed from cloned DNA in Escherichia coli. Phytopathology $79: 1246-1249$.

25. Shaw, J.J. and Kado, C.I. (1986). Development of a Vibrio bioluminescence gene-set to monitor phytopathogenic bacteria during the ongoing disease process in a non-disruptive manner. Bio/Technology $4: 560-564$.

26. Shaw, J.J., Settles, L.G. and Kado, C.I. (1988). Transposon Tn4431 mutagenesis of Xanthomonas campestris pv. campestris: Characterization of a nonpathogenic mutant and cloning of a locus for pathogenicity. Mol. Plant-Microbe Interact. $1: 39-45$.

27. Smibert, R.M. and Krieg, N.R. (1981). General characterization. In Manual of methods for general bacteriology (Krieg, N.R. ed.). American Society for Microbiology, Washington, D.C. pp. 409-443.

28. Sneh, B., Katan, J. and Henis, Y. (1971). Mode of inhibition of Rhizoctonia solani in chitin-amended soil. Phytopathology 61: 1113-1117. 
29. Sneh, B. (1981). Use of rhizosphere chitinolytic bacteria for biological control of Fusarium oxysporum f. sp. dianthi in carnation. Phytopathol. Z. $100: 251-256$.

30. Sneh, B., Agami, O. and Baker, R. (1985). Biological control of Fusarium-wilt in carnation with Serratia liquefaciens and Hefnia alvei isolated from rhizosphere of carnation. Phytopathol. Z. 113:271-276.

31. Toyoda, H., Katsuragi, K., Tamai, T. and Ouchi, S. (1991), DNA sequence of genes for detoxification of fusaric acid, a wilt-inducing agent produced by Fusarium species. J. Phytopathol. 133: 265-277.

32. Weller, D.M. (1988). Biological control of soilborne plant pathogens in the rhizosphere with bacteria. Ann. Rev. Phytopathol. $26: 379-407$.

33. Willetts, N. and Wilkins, B. (1984). Processing of plasmid DNA during bacterial conjugation. Microbiol. Rev. $48: 24-41$.

和 文 摘 要

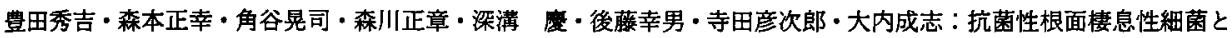
キチン分解性放線菌によるトマト萎ちょう病の生物防除

トマトの要ちょう病菌を防除するため，抗菌性根面捿息性細菌とキチン分解性放線菌を併用した生物防除法を確立 した。まず，トマト根磨砕液から分離した根面細菌(Serratia marcescens)をlux 遗后子およびテトラサイクリン抵抗性 遺伝子で標識し,トマト種子をコーティングした後, 土埕に播種してその挙動を追跡した。本菌は新たに形成されたト マト根にも定着したが，その細菌密度は根の伸長とともに低下した。そこで, 本菌がキチン分解産物を資化できること に着目し，コーティング種子をキチン分解性放線菌(Streptomyces anulatus)を優先化させたキキン添加土㙴に播種し た。その結果, 伸長した根においても高密度の根面細菌が分離され，萎ちょう病に高い防除効果を示したので，キチン 分解性放線菌によって得られた分解産物が根面細菌の増殖を促進したことにより効果的な防除結果が得られたものと 考え，本法を Binary microbe system と名付けた。

\section{Explanation of plate}

Plate I Root-colonizing bacterium, Serratia marcescens KM-201, and chitin-degrading microbe, Streptomyces anulatus TM-3, used for the binary microbe system.

1. Bacterial isolates (arrows) suppressing the mycelial growth of $F$. oxysporum $\mathrm{f}$. sp. lycopersici, race J 1 . The isolate (larger arrow) showing the strongest antifungal activity was isolated and identified as $S$. marcescens.

2. KM-201 colonizing on tomato roots. Numbers in the photograph represent densities of bacterial suspension used for immersing tomato seeds.

3. Antifungal activities of KM-20I (A) and its transconjugant KM-201/lux (B) pair-cultured with $F$. oxysporum f. sp. lycopersici. Note the stronger antifungal activities of KM-201 and KM 201/lux than other isolates and the similar level of activities between these two bacteria.

4. Bioluminescence produced by KM-201/lux streaked onto the selective CCp medium containing $10 \mu \mathrm{g} / \mathrm{ml}$ tetracycline.

5. Tomato seedling (A) derived from a KM-201/lux-coated seed grown for 2 weeks in non-sterilized soil, and bioluminescence (B) by KM-201/lux colonized on newly elongated roots.

6. Antifungal activity of KM-201/lux tested by the spore-plate method. KM-201/lux cross-streaked onto CCpA medium suppressed the mycelial growth of the pathogen ( $F$. oxysporum f. sp. lycopersici) embedded in the spore-plate.

7. Halo produced by a chitin-degrading microbe TM-3 embedded in CCA medium (10 days after incubation).

8. Protection of tomato plants from the disease by the binary microbe system. Tomato seeds coated with KM-201/lux were sown in TM-3 treated chitin-amended soil (right) and non-coated seeds in chitin-free soil without TM-3 (left). 
Plate I
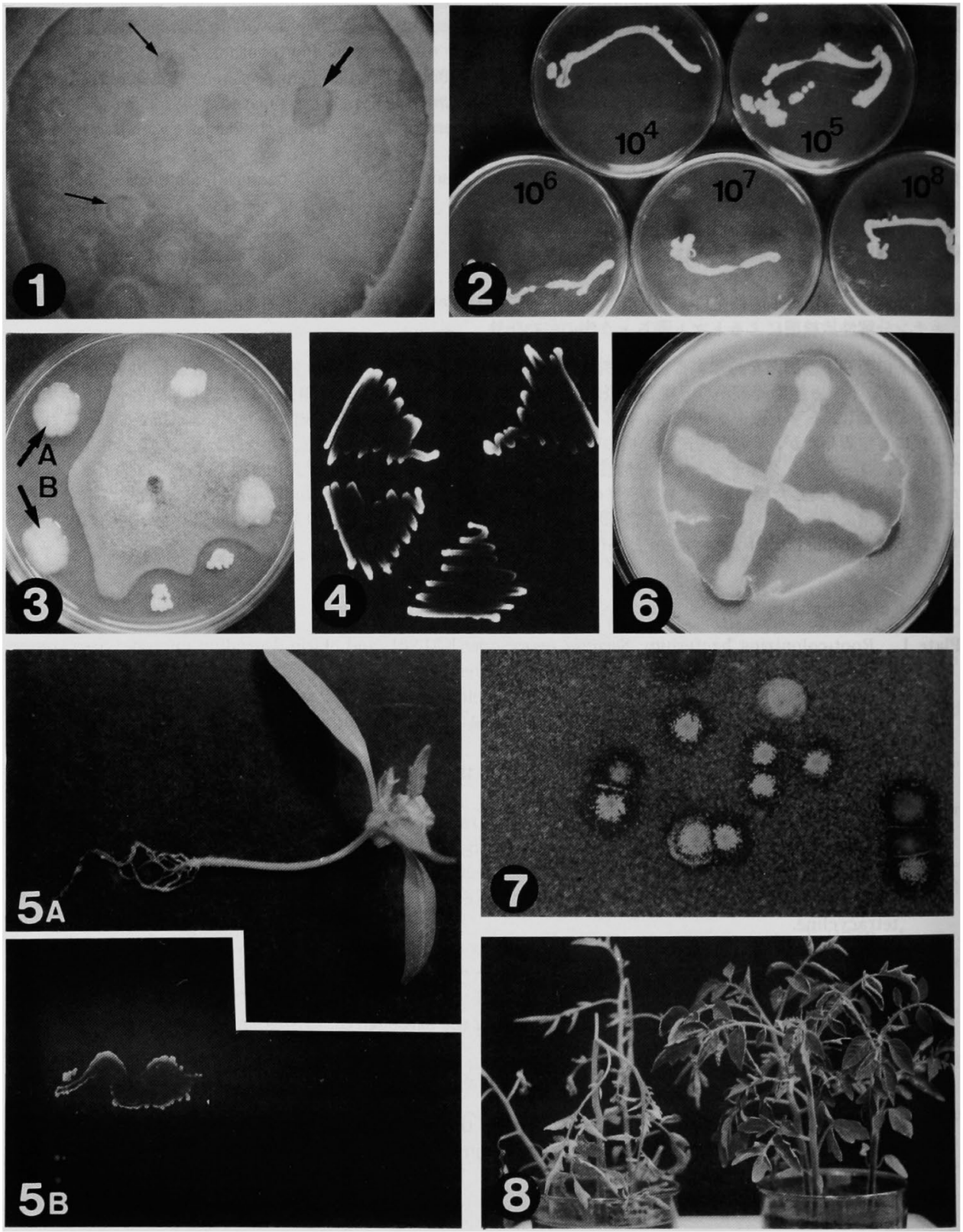